\title{
Hepatitis B Virus e Antibody Measurement
}

National Cancer Institute

\section{Source}

National Cancer Institute. Hepatitis B Virus e Antibody Measurement. NCI Thesaurus. Code C96662.

The determination of the amount of Hepatitis B virus e antibody present in a sample. 